Check for updates

Cite this: RSC Adv., 2017, 7, 54726

\title{
Comparison of phytolith-occluded carbon in 51 main cultivated rice (Oryzasativa) cultivars of China
}

\author{
Xing Sun, (D) a Qin Liu, (D) $\uparrow^{* \mathrm{~b}}$ Gengmao Zhao, (D) ${ }^{\mathrm{c}}$ Xiang Chen, (D) $\dagger^{\mathrm{b}}$ \\ Tongtong Tang $\left(\mathbb{D} \dagger^{b}\right.$ and Yuyong Xiang $\left(\mathbb{D}^{a}\right.$
}

In this study, the carbon (i.e., C) bio-sequestration within phytoliths (PhytOC) in 51 rice cultivars was evaluated to breed cultivars with a high efficiency of carbon sequestration in phytoliths and high productivity. The phytolith extraction from rice plants was achieved through wet digestion procedures, and the $\mathrm{C}$ content of phytoliths was determined using an Elemental Analyzer 3000. The phytolith contents in the rice organs ranged from 9.69 to $175.52 \mathrm{mg} \mathrm{g}^{-1}$, with significant differences in the phytolith contents in the different organs of each rice cultivar. The estimated PhytOC fluxes of rice plants in 51 rice cultivars were approximately $0.006-0.035 \mathrm{Mg}-\mathrm{e}-\mathrm{CO}_{2}$ per ha per year. High variation coefficients of phytoliths and contents of phytoliths of plant in indica and japonica rice cultivars implied considerable variation among these rice cultivars. Additional results showed no correlation between the phytolith contents and the $C$ content of phytoliths $(R=0.170, p>0.05)$, and the $C$ content of phytoliths was significantly correlated with the PhytOC content in dry plant weight $(R=0.804, p<0.01)$. However, the estimated PhytOC flux was significantly correlated with the phytolith content $R=0.651, p<0.01)$, with the $C$ content of phytoliths $(R=0.512, p<0.01)$ and with the PhytOC content in dry plant weight $(R=0.727, p<0.01)$. Selected rice cultivars herein with a high efficiency of $C$ sequestration in phytoliths and high productivity, therefore, played important roles in controlling the $C$ sink and Si biogeochemical cycle in soil-rice systems.

Received 27th September 2017 Accepted 22nd November 2017 DOI: $10.1039 / \mathrm{c} 7 \mathrm{ra10685h}$

rsc.li/rsc-advances sheath, leaf and grains) ranged from 15.47-143.95 $\mathrm{mg} \mathrm{g}^{-1}$ and 12.46-26.39 $\mathrm{mg} \mathrm{g}^{-1}$, respectively. Similar results and trends were reported by other researchers. ${ }^{8}$

Some studies have considered that PhytOC is derived through photosynthesis,,$^{3,8,18-20}$ of which $1-6 \%$ is typically occluded within phytolith. ${ }^{19}$ The phytolith content in plant matter varied greatly among different crop types $(0.37-8.38 \%$, average $3.68 \%$ ) and even among crop species of the same crop types. $^{20}$ Recent studies have shown that the global $\mathrm{CO}_{2}$ sequestration in rice phytoliths is $1.97 \times 10^{7} \mathrm{Mg}$-e- $\mathrm{CO}_{2}$ per year, ${ }^{6}$ and this value is slightly lower compared with wetland plants $\left(4.39 \times 10^{7} \mathrm{Mg} \text {-e- } \mathrm{CO}_{2} \text { per year }\right)^{7}$ and higher compared

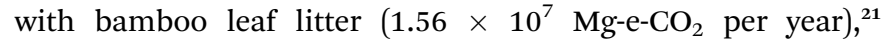
sugarcane leaves $\left(0.72 \times 10^{7} \mathrm{Mg}\right.$-e- $\mathrm{CO}_{2}$ per year $),{ }^{22}$ and millet $\left(2.37 \times 10^{6} \mathrm{Mg}\right.$-e- $\mathrm{CO}_{2}$ per year $) .{ }^{4}$ After plants return to the soil, decomposition through microorganisms is initiated, and phytoliths in straws are released directly into the soil. ${ }^{23-25}$ Phytoliths can tolerate extreme environments, such as earthquakes, dust storms, floods, forest fire erosion, etc., and are often retained in the in situ environment. ${ }^{\mathbf{1 0 2 6 - 3 0}}$ The phytolith decomposition rate depends on the solubility of these molecules, which is similar to amorphous $\mathrm{Si}\left(10^{-2.74}\right)$ and falls between Si glass $\left(10^{-2.71}\right)$ and quartz $\left(10^{-4.00}\right){ }^{31}$ Thus, because of the stability of phytolith, the $\mathrm{C}$ occluded within phytoliths is relatively stable and persists in the soil for a millennium, reflecting a strong resistance to 
decomposition, compared with other organic matter fractions. Indeed, PhytOC can be retained for a thousand years, ${ }^{19,27,28,32,33}$ and phytoliths can contribute $15-37 \%$ of long-term biogeochemical C sequestration. ${ }^{19}$ Thus, PhytoC plays a major role in the soil C cycle, ${ }^{19}$ and the importance of this molecule in relation to climate change has been emphasized..$^{3,8,18,34-36}$

Rice is a staple crop grown on nearly every continent worldwide, with a global rice-planting area of approximately $1.64 \times 10^{8}$ ha in $2014 . .^{14}$ As a Si accumulator, contains several phytoliths and can occlude more organic $\mathrm{C}$ in its organs compared with other plants. ${ }^{3}$ China, as one of the largest cropproducing countries worldwide, has approximately $1.60 \times 10^{8}$ ha of crop lands, ${ }^{37}$ of which $3.03 \times 10^{7}$ ha is rice cropland. ${ }^{38}$ Thus, the PhytOC of rice croplands may represent the magnitude of the C sink in cropland ecosystems. ${ }^{3,19}$ According to the correlations between the phytolith content and the PhytOC content in crops, these results showed that the PhytOC content of plants can be increased by crop species or cultivar optimization. ${ }^{6,20,39}$ However, the variability of phytolith and PhytOC accumulation within more cultivars of rice has not previously been examined. In the present study, we evaluated PhytOC produced in the rice plants of 51 rice cultivars. The aim of the present study was to select rice cultivars with a high efficiency of $\mathrm{C}$ sequestration in phytoliths and high productivity, to increase the $\mathrm{C}$ long-term sequestration in phytoliths, reduce $\mathrm{CO}_{2}$ emissions and relieve the environmental stress resulting from greenhouse gas emissions.

\section{Methods}

\subsection{Rice cultivars}

The samples of 51 rice cultivars (Oryza sp.), belonging to six varieties, were randomly obtained from six provinces (Jiangxi, Jiangsu, Henan, Heilongjiang, Anhui and Zhejiang) of China in June 2013. The cultivars were derived from the conventional cultivars in the locality, and were used to examine the phytolith accumulation, determine the PhytOC yield, and estimate the PhytOC fluxes in different rice cultivars every year.

\subsection{Experimental site}

In the present study, to avoid the influence of some factors, the root, stem, leaf, sheath and grain of 51 cultivars of rice were grown on the same permeable paddy soil under the same environmental conditions at Changshu Agroecological Experimental Station, Chinese Academy of Sciences. The base is located in the county of Xinzhuang, South Changshu, Suzhou, Jiangsu Province, P. R. China $\left(31^{\circ} 32^{\prime} 88^{\prime \prime} \mathrm{N} / 120^{\circ} 41^{\prime} 88^{\prime \prime} \mathrm{E}\right)$. The geology of the study site comprised the incubation and development of paddy soils in part of Taihu Lake in the Yangtze Delta plain. The climate in this region is a subtropical humid climate of the Central District, with an annual average temperature of $16.6^{\circ} \mathrm{C}$ and an annual average rainfall of $1321 \mathrm{~mm}$, and a ricewheat rotation system prevailed in this region. The initial soil had a pH of 7.54, $39.89 \mathrm{~g} \mathrm{~kg}^{-1}$ of organic matter, $2.40 \mathrm{~g} \mathrm{~kg}^{-1}$ of total $\mathrm{N}, 0.73 \mathrm{~g} \mathrm{~kg}^{-1}$ of total $\mathrm{P}, 20.16 \mathrm{~g} \mathrm{~kg}^{-1}$ of total $\mathrm{K}$, $34.27 \mathrm{mg} \mathrm{kg}^{-1}$ of $\mathrm{Na}_{2} \mathrm{CO}_{3}$-extractable $\mathrm{P}, 101.7 \mathrm{mg} \mathrm{kg}^{-1}$ of $\mathrm{NH}_{4} \mathrm{OAc}$-extractable $\mathrm{K}$ and $252.3 \mathrm{mg} \mathrm{kg}{ }^{-1}$ of $\mathrm{NH}_{4} \mathrm{OAc}-$ extractable Si.

\subsection{Sample preparation}

After rice cultivars harvest, each rice plant was separated into five different organs: root, stem, leaf, sheath and grain. All rice samples were rinsed twice in distilled water and placed in an ultrasonic bath for $20 \mathrm{~min}$ and subsequently dried at $70{ }^{\circ} \mathrm{C}$ for $24 \mathrm{~h}$. After hulling, the rice samples were preserved for phytolith extraction and PhytOC analysis.

\subsection{Phytolith extraction from rice organs and PhytOC measurements}

The phytolith was extracted using a revised wet digestion procedure described in detail by Sun et al. , $^{\mathbf{4} 0}$ Phytolith residue assemblages were mounted onto glass slides in Balsam Canada mounting medium. Slides were viewed by scanning electron microscope (SEM) to ensure that no organic material exists according to Parr and Sullivan (Fig. 1). ${ }^{41}$ The PhytOC was determined using an Elemental Analyzer 3000 (GmbH Company, Germany).

\subsection{Statistical analyses}

The mean values of all parameters were determined from the measurements of three replicates, and the standard error of the means was calculated. One-way ANOVA was applied to determine the significance of the results between different varieties, and subsequently, Turkey's multiple range tests $(p<0.05)$ were

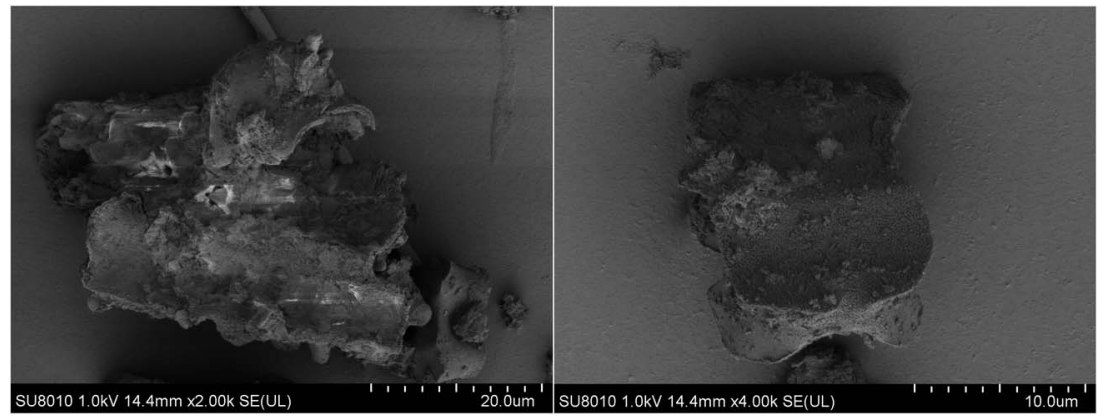

Fig. 1 SEM images of phytoliths extracted from the rice samples using the wet ashing method according to Zuo (2011) and Sun (2016). 
performed. All of the statistical analyses were performed using SPSS v.17 for Windows.

\section{Results and discussion}

\subsection{Phytolith and PhytOC contents of different organs in $\mathbf{5 1}$} rice cultivars

Phytoliths content of plant is affected by many factors like location, soil type, climate, management practices. ${ }^{\mathbf{8 , 2 1 , 4 2 , 4 3}}$ To avoid the influence of these factors, in the present study, the collected rice seeds were planted in a multi-year paddy (the same basic soil nutrient status, the same climate condition and the same water and fertilizer management, etc.) and final estimates of the PhytOC flux artificially unified the biomass. The samples of 51 rice cultivars (Oryza sp.), the conventional cultivars in the locality, were randomly obtained from six provinces of China and were grown on the same permeable paddy soil under the same environmental conditions at Changshu Agroecological Experimental Station, Chinese Academy of Sciences. After harvest, the phytoliths extracted from the rice samples using the wet ashing method and the SEM image of phytolith was showed at Fig. 1. The phytolith contents of rice organs (root, stem, sheath, leaf and grains) were different. The phytolith contents ranged from 9.69 to $175.52 \mathrm{mg} \mathrm{g}^{-1}$ (Fig. 2). The phytoliths content of root, sheath and leaf were higher than these of stem and grains. The phytolith content of grains was lowest of the rice organs. The shape of phytoliths in different organs were different (e.g., double-peaked, bulliform and paralleled dumbbell phytoliths). ${ }^{6,14}$ Li et al. ${ }^{6}$ and Prajapati et al. ${ }^{14}$ reported that the phytoliths content in different rice organs (stem, sheath, leaf and grains) ranged from $15.47-143.95 \mathrm{mg} \mathrm{g}^{-1}$ and $12.46-$ $26.39 \mathrm{mg} \mathrm{g}^{-1}$, respectively. The similar results and trends were reported by other researcher. ${ }^{8}$

In addition, the $\mathrm{C}$ contents of phytoliths substantially varied in different rice cultivars. The $\mathrm{C}$ contents of phytoliths ranged from 0.43 to $15.46 \mathrm{mg} \mathrm{g}^{-1}$ (Fig. 3), and the PhytOC content in dry organs weight ranged from 0.017 to $0.97 \mathrm{mg} \mathrm{g}^{-1}$ (Fig. 4). The phytolith content in plant matter greatly varied among different crop types (0.37-8.38\%, average $3.68 \%)$ and even among crop species of the same crop types. ${ }^{20}$ The similar results and trends were reported by many researchers. ${ }^{6,8,14}$ Many studies analysing the physical and chemical properties of phytoliths have shown

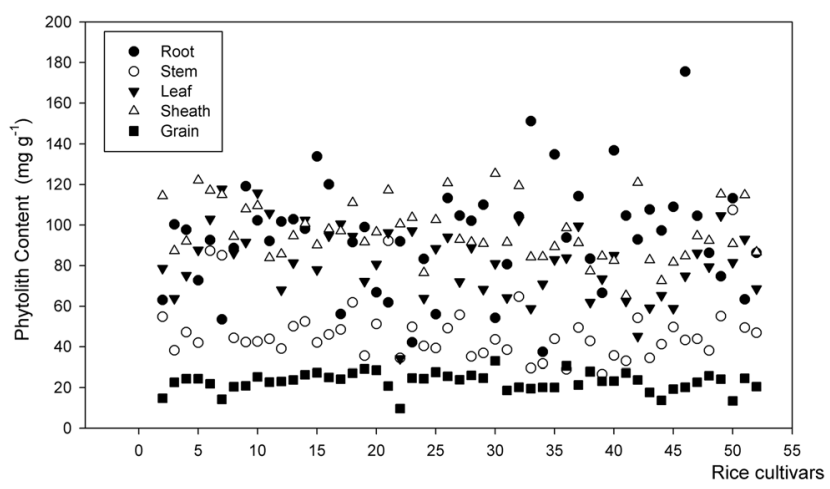

Fig. 2 Phytoliths content of different organs of rice cultivars.

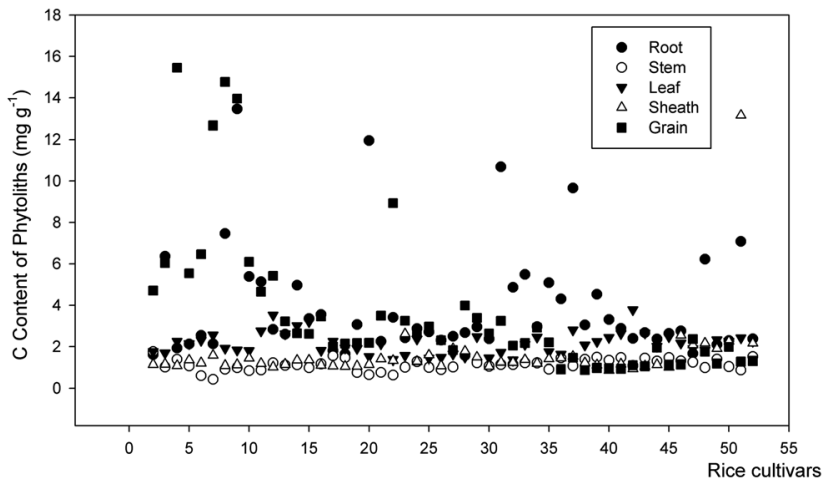

Fig. $3 \mathrm{C}$ content of phytoliths in different organs of rice cultivars.

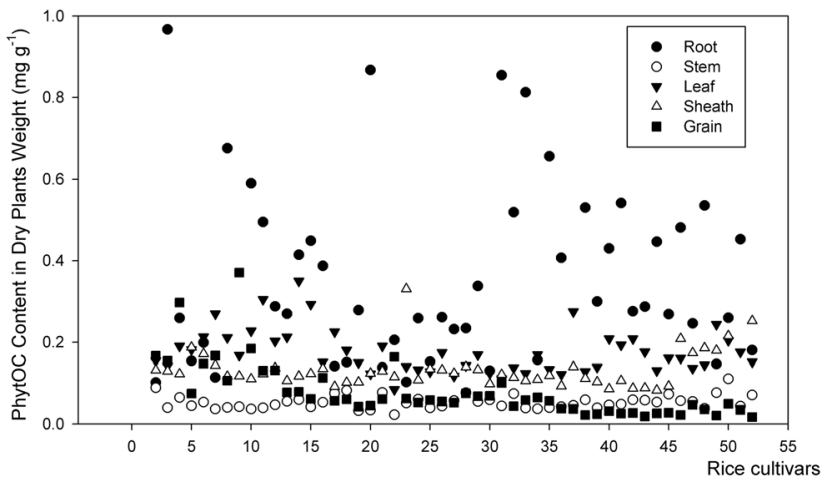

Fig. 4 PhytOC content in dry plant weight in different organs of rice cultivars.

that the phytoliths can occlude $\mathrm{C}$ to levels ranging from 2 to $58 \mathrm{mg} \mathrm{g}^{-1} .^{34}$ The occlusion of $\mathrm{C}$ within phytoliths has been retained in soils for more than a millennium, generating an important long-term terrestrial C fraction..$^{28,38-40}$ Thus, appropriate measures can improve the phytolith content of crops through enhancing soil available Si contents, ${ }^{39}$ aboveground net primary productivity, ${ }^{44}$ cultivar selection, ${ }^{4,21,22}$ nitrogen application, ${ }^{43}$ and basalt powder amendment, ${ }^{8}$ etc. Its mechanism will be considered in future work.

The production of PhytOC fluxes in rice organs are depends primarily on the dry weight, phytolith content, C content of phytolith of various plant parts and the total dry biomass. ${ }^{6,14}$ According to the before data, we estimated PhytOC fluxes in rice, and these results showed different fluxes of PhytOC in 51 rice cultivars (from 0.12 to 8.95 kg-e- $\mathrm{CO}_{2}$ per ha per year) (Fig. 5). The estimated PhytOC fluxes of different organs (root, stem, sheath, leaf and grains) ranged from 0.12 to $8.95 \mathrm{~kg}$-e- $\mathrm{CO}_{2}$ per ha per year, 0.43 to $1.55 \mathrm{~kg}$-e- $\mathrm{CO}_{2}$ per ha per year, 1.28 to $6.24 \mathrm{~kg}$ e- $\mathrm{CO}_{2}$ per ha per year, 1.20 to $5.69 \mathrm{~kg}$-e- $\mathrm{CO}_{2}$ per ha per year, 0.44 to $6.57 \mathrm{~kg}$-e- $-\mathrm{CO}_{2}$ per ha per year, respectively. The estimated PhytOC fluxes of stem were lowest of the rice organs.

\subsection{Phytolith and PhytOC contents in 51 rice cultivars}

The phytolith and C contents of phytoliths in 51 rice cultivars were significantly different (Tables 1 and 2). The phytolith 


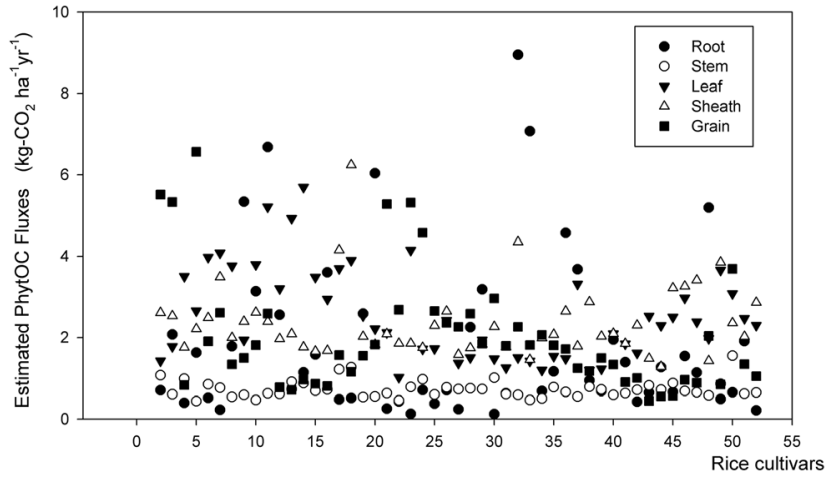

Fig. 5 Estimated PhytOC fluxes in different organs of rice cultivars.

contents ranged from 53.83 to $77.15 \mathrm{mg} \mathrm{g}^{-1}$ in indica rice cultivars and 45.64 to $78.89 \mathrm{mg} \mathrm{g}^{-1}$ in japonica rice cultivars. The ranges of $\mathrm{C}$ contents of phytoliths in indica and japonica rice cultivars were 1.21 to $7.21 \mathrm{mg} \mathrm{g}^{-1}$ and 1.56 to $5.24 \mathrm{mg} \mathrm{g}^{-1}$, respectively, and the PhytOC content in dry plant weight ranged from 0.09 to $0.51 \mathrm{mg} \mathrm{g}^{-1}$ and 0.08 to $0.38 \mathrm{mg} \mathrm{g}^{-1}$. According to the before data and biomass of single rice crops, we estimated PhytOC fluxes in rice, and these results showed different PhytOC fluxes in 19 indica rice cultivars (from 0.007 to $0.035 \mathrm{Mg}$-e$\mathrm{CO}_{2}$ per ha per year) (Table 1) and 32 japonica rice cultivars (from $0.006 \mathrm{Mg}$-e- $\mathrm{CO}_{2}$ per ha per year to $0.035 \mathrm{Mg}$-e- $\mathrm{CO}_{2}$ per ha per year); these values were significantly different among the 51 rice cultivars. Many workers reported that the PhytOC sequestration rate can be obtained by selecting high PhytOC cultivars. ${ }^{2,6,8,21}$ This study also showed that high PhytOC sequestration rate rice cultivars may be selected in indica rice and japonica rice cultivars.
In the present study, we estimated that the $\mathrm{C}$ fluxes of the rice plants were 0.006 and $0.035 \mathrm{Mg}$-e- $\mathrm{CO}_{2}$ per ha per year in terms of the PhytOC in rice plant material on a dry weight basis. ${ }^{45}$ However, Li, Z. et al. ${ }^{6}$ and Prajapati et al. ${ }^{14}$ reported that the flux of the rice PhytOC is 0.03-0.13 $\mathrm{Mg}$-e- $\mathrm{CO}_{2}$ per ha per year, and $0.05-0.12 \mathrm{Mg}$-e- $\mathrm{CO}_{2}$ per ha per year, which was higher than the results obtained in the present study. ${ }^{6}$ The differences between these results might reflect (i) the number of tested cultivars (i.e., this manuscript tested 51 rice cultivars, and Li et al. ${ }^{6}$ tested only 5 rice cultivars); (ii) the Si content of the paddy field, for example, previous studies have demonstrated that soil with high Si could enhance the phytolith content in crops; ${ }^{46-48}$ and (iii) the tested measure (i.e., this manuscript examined a revision to the wet digestion method, and Li et al. examined the microwave digestion method $\left.{ }^{6}\right)$. But still it is likely that breeding for high PhytOC rice cultivars would result in more amount of securely bio-sequestered $\mathrm{C}$ in rice crops.

\subsection{Phytolith and PhytOC contents in 6 rice varieties}

The phytolith and C contents of phytoliths in 6 rice varieties were not significantly different. The phytolith contents ranged from 57.87 to $67.52 \mathrm{mg} \mathrm{g}^{-1}$ in 6 rice varieties. The $\mathrm{C}$ contents of phytoliths ranged from 2.10 to $3.05 \mathrm{mg} \mathrm{g}^{-1}$, and subsequently, the PhytOC content in dry plant weight ranged from 0.13 to $0.21 \mathrm{mg} \mathrm{g}^{-1}$. According to the before data and biomass of single rice crops, we estimated PhytOC fluxes in rice, and these results showed no difference in the PhytOC fluxes in 6 rice cultivars (from 0.009 to $0.012 \mathrm{Mg}$-e- $\mathrm{CO}_{2}$ per ha per year) (Table 3), thus, there were no significant differences among the 6 rice varieties.

Table 1 Indica rice cultivars, phytolith content, $\mathrm{C}$ content of phytoliths, PhytOC of rice plants on a dry weight basis, and estimated PhytOC fluxes per ha in $\mathrm{Mg}$ of $\mathrm{CO}_{2}$ equivalents $\left(\mathrm{Mg}-\mathrm{e}-\mathrm{CO}_{2}\right.$ ) for rice (according to grain yields of single and double indica rice crops between 11.25 and $22.5 \mathrm{Mg}$ $\left.\mathrm{ha}^{-1}\right)^{a}$

\begin{tabular}{|c|c|c|c|c|}
\hline Cultivars & $\begin{array}{l}\text { Phytolith content } \\
\left(\mathrm{mg} \mathrm{g}^{-1}\right)\end{array}$ & $\begin{array}{l}\text { C content of phytoliths } \\
\left(\mathrm{mg} \mathrm{g}^{-1}\right)\end{array}$ & $\begin{array}{l}\text { PhytOC content in dry } \\
\text { plant weight }\left(\mathrm{mg} \mathrm{g}^{-1}\right)\end{array}$ & $\begin{array}{l}\text { Estimated PhytOC fluxes } \\
\left(\mathrm{Mg}-\mathrm{CO}_{2} \text { per ha per year }\right)\end{array}$ \\
\hline Zhonghan 35 & $59.47 \pm 6.45 \mathrm{ab}$ & $5.09 \pm 3.96 \mathrm{ab}$ & $0.31 \pm 0.24 \mathrm{abc}$ & $0.011-0.023$ \\
\hline Guichao 2 & $53.83 \pm 14.76 b$ & $4.06 \pm 2.35 \mathrm{abc}$ & $0.21 \pm 0.09 b c$ & $0.012-0.025$ \\
\hline Xinliangyou 6 & $60.31 \pm 5.13 \mathrm{ab}$ & $1.21 \pm 0.02 \mathrm{c}$ & $0.09 \pm 0.01 \mathrm{c}$ & $0.007-0.015$ \\
\hline Rongyou 463 & $67.04 \pm 1.56 \mathrm{ab}$ & $4.11 \pm 0.31 \mathrm{abc}$ & $0.29 \pm 0.03 \mathrm{abc}$ & $0.013-0.027$ \\
\hline Tianyou 998 & $77.15 \pm 17.96 a$ & $7.21 \pm 5.28 \mathrm{a}$ & $0.50 \pm 0.30 \mathrm{a}$ & $0.018-0.035$ \\
\hline Yueyou 9114 & $74.63 \pm 18.71 \mathrm{ab}$ & $3.13 \pm 0.72 b c$ & $0.24 \pm 0.05 b c$ & $0.011-0.022$ \\
\hline Gangyou 188 & $59.48 \pm 2.17 \mathrm{ab}$ & $1.80 \pm 0.17 b c$ & $0.11 \pm 0.01 c$ & $0.009-0.019$ \\
\hline Ilyou 1259 & $60.32 \pm 5.23 \mathrm{ab}$ & $2.05 \pm 0.40 \mathrm{bc}$ & $0.13 \pm 0.01 \mathrm{c}$ & $0.012-0.025$ \\
\hline IIyou 501 & $72.45 \pm 11.83 \mathrm{ab}$ & $1.94 \pm 0.31 b c$ & $0.15 \pm 0.04 b$ & $0.012-0.024$ \\
\hline Fuyou 21 & $64.89 \pm 14.85 \mathrm{ab}$ & $3.43 \pm 1.47 \mathrm{bc}$ & $0.24 \pm 0.15 b c$ & $0.018-0.035$ \\
\hline Chuannong 1 & $60.21 \pm 2.86 \mathrm{ab}$ & $1.54 \pm 0.30 \mathrm{bc}$ & $0.10 \pm 0.01 \mathrm{c}$ & $0.009-0.018$ \\
\hline Zhongyou 7 & $61.86 \pm 6.44 \mathrm{ab}$ & $1.40 \pm 0.40 \mathrm{bc}$ & $0.10 \pm 0.03 c$ & $0.009-0.019$ \\
\hline Yixiang 2079 & $68.96 \pm 4.43 \mathrm{ab}$ & $1.46 \pm 0.11 b c$ & $0.11 \pm 0.00 c$ & $0.010-0.021$ \\
\hline Ilyou 1313 & $60.06 \pm 3.87 \mathrm{ab}$ & $1.29 \pm 0.11 b c$ & $0.09 \pm 0.01 \mathrm{c}$ & $0.008-0.017$ \\
\hline Yixiang 725 & $74.17 \pm 18.94 \mathrm{ab}$ & $1.36 \pm 0.40 \mathrm{bc}$ & $0.12 \pm 0.06 \mathrm{c}$ & $0.010-0.020$ \\
\hline Nenyou 8015 & $64.18 \pm 7.53 \mathrm{ab}$ & $1.85 \pm 0.40 \mathrm{bc}$ & $0.14 \pm 0.03 c$ & $0.011-0.022$ \\
\hline Qianyou 0508 & $82.00 \pm 21.83 a$ & $2.28 \pm 0.27 \mathrm{bc}$ & $0.17 \pm 0.04 \mathrm{ab}$ & $0.014-0.027$ \\
\hline Tenuo 2072 & $60.41 \pm 9.32 \mathrm{ab}$ & $1.64 \pm 0.46 b c$ & $0.11 \pm 0.04 c$ & $0.009-0.018$ \\
\hline Zhenzhunuo & $64.73 \pm 4.75 \mathrm{ab}$ & $2.32 \pm 1.03 \mathrm{bc}$ & $0.16 \pm 0.08 b c$ & $0.012-0.025$ \\
\hline
\end{tabular}

${ }^{a}$ Data obtained from the Changshu Agroecological Experimental Station, Chinese Academy of Sciences. 
Table 2 Japonica rice cultivars, phytolith content, C content of phytoliths, PhytOC of rice plants on a dry weight basis, and estimated PhytOC fluxes per ha in $\mathrm{Mg}$ of $\mathrm{CO}_{2}$ equivalents $\left(\mathrm{Mg}-\mathrm{e}-\mathrm{CO}_{2}\right)$ for rice (according to grain yields of single and double indica rice crops between 9.28 and $\left.18.56 \mathrm{Mg} \mathrm{ha}^{-1}\right)^{a}$

\begin{tabular}{|c|c|c|c|c|}
\hline Cultivars & $\begin{array}{l}\text { Phytolith content } \\
\left(\mathrm{mg} \mathrm{g}^{-1}\right)\end{array}$ & $\begin{array}{l}\text { C content of phytoliths } \\
\left(\mathrm{mg} \mathrm{g}^{-1}\right)\end{array}$ & $\begin{array}{l}\text { PhytOC content in dry } \\
\text { plant weight }\left(\mathrm{mg} \mathrm{g}^{-1}\right)\end{array}$ & $\begin{array}{l}\text { Estimated PhytOC fluxes } \\
\left(\mathrm{Mg}-\mathrm{CO}_{2} \text { per ha per year }\right)\end{array}$ \\
\hline Huaidao 5 & $62.96 \pm 6.02 \mathrm{abc}$ & $4.17 \pm 1.38 \mathrm{ab}$ & $0.27 \pm 0.07 \mathrm{abc}$ & $0.010-0.021$ \\
\hline Wuyunjeng 7 & $65.55 \pm 6.53 \mathrm{abc}$ & $4.04 \pm 1.68 \mathrm{abc}$ & $0.27 \pm 0.10 \mathrm{abcd}$ & $0.012-0.024$ \\
\hline Xindao 20 & $53.37 \pm 2.83 \mathrm{abc}$ & $3.55 \pm 1.36 \mathrm{abcde}$ & $0.20 \pm 0.06 \mathrm{bcdef}$ & $0.010-0.019$ \\
\hline Shengdao 16 & $64.54 \pm 1.23 \mathrm{abc}$ & $2.11 \pm 0.44 \mathrm{def}$ & $0.15 \pm 0.03 b c$ & $0.008-0.015$ \\
\hline Lianjing 11 & $62.86 \pm 9.66 \mathrm{abc}$ & $2.17 \pm 0.43 \mathrm{cdef}$ & $0.15 \pm 0.03 b c$ & $0.009-0.018$ \\
\hline Yanjing 47-12 & $65.55 \pm 3.87 \mathrm{abc}$ & $2.26 \pm 0.50 \mathrm{cdef}$ & $0.16 \pm 0.05 \mathrm{cdef}$ & $0.010-0.019$ \\
\hline Wuyunjing 21 & $69.43 \pm 8.45 \mathrm{abc}$ & $1.91 \pm 0.32 \mathrm{def}$ & $0.15 \pm 0.04 \mathrm{cdef}$ & $0.008-0.016$ \\
\hline Zhengdao 18 & $45.64 \pm 1.01 \mathrm{c}$ & $2.19 \pm 0.70 \mathrm{cdef}$ & $0.11 \pm 0.03 \mathrm{ef}$ & $0.006-0.012$ \\
\hline Jin G2 & $78.89 \pm 21.24 \mathrm{a}$ & $3.65 \pm 1.50 \mathrm{abcd}$ & $0.31 \pm 0.20 \mathrm{ab}$ & $0.018-0.035$ \\
\hline Zhonghua 11 & $58.80 \pm 17.19 a b c$ & $2.39 \pm 0.15$ bcdef & $0.15 \pm 0.04 \mathrm{cdef}$ & $0.012-0.024$ \\
\hline Longdao 12 & $57.63 \pm 6.65 \mathrm{abc}$ & $1.62 \pm 0.25 \mathrm{ef}$ & $0.11 \pm 0.01 \mathrm{ef}$ & $0.007-0.014$ \\
\hline Longjing 21 & $48.45 \pm 2.80 a b c$ & $1.76 \pm 0.11 \mathrm{def}$ & $0.10 \pm 0.01 \mathrm{ef}$ & $0.006-0.012$ \\
\hline Longjing 36 & $56.10 \pm 10.32 \mathrm{abc}$ & $1.80 \pm 0.04 \mathrm{def}$ & $0.11 \pm 0.02 \mathrm{ef}$ & $0.008-0.016$ \\
\hline Suidao 3 & $48.38 \pm 5.18 \mathrm{abc}$ & $1.54 \pm 0.35 f$ & $0.09 \pm 0.02 \mathrm{ef}$ & $0.007-0.013$ \\
\hline Jixidao 1 & $54.67 \pm 17.18 \mathrm{abc}$ & $1.44 \pm 0.13 \mathrm{f}$ & $0.09 \pm 0.03 \mathrm{ef}$ & $0.006-0.012$ \\
\hline Nanjing 5055 & $52.41 \pm 9.31 \mathrm{abc}$ & $1.29 \pm 0.11 \mathrm{f}$ & $0.08 \pm 0.01 \mathrm{f}$ & $0.006-0.012$ \\
\hline Nanjing 46 & $53.44 \pm 8.36 \mathrm{abc}$ & $1.51 \pm 0.19 f$ & $0.09 \pm 0.01 \mathrm{ef}$ & $0.006-0.012$ \\
\hline Xiushui 09 & $52.75 \pm 5.98 \mathrm{abc}$ & $1.68 \pm 0.14 \mathrm{ef}$ & $0.10 \pm 0.01 \mathrm{ef}$ & $0.008-0.016$ \\
\hline Zhejing 88 & $64.21 \pm 5.42 \mathrm{abc}$ & $2.02 \pm 0.26 \mathrm{def}$ & $0.14 \pm 0.01 \mathrm{cdef}$ & $0.09-0.019$ \\
\hline Xiushui 134 & $65.50 \pm 3.65 \mathrm{abc}$ & $1.51 \pm 0.68 \mathrm{f}$ & $0.11 \pm 0.04 \mathrm{ef}$ & $0.008-0.017$ \\
\hline 8you 682 & $63.84 \pm 9.29 a b c$ & $2.61 \pm 0.58 \mathrm{bcdef}$ & $0.18 \pm 0.06 \mathrm{bcdef}$ & $0.011-0.022$ \\
\hline Zheyou 12 & $68.42 \pm 4.61 \mathrm{abc}$ & $1.62 \pm 0.19 \mathrm{ef}$ & $0.12 \pm 0.01 \mathrm{def}$ & $0.010-0.019$ \\
\hline
\end{tabular}

${ }^{a}$ Data obtained from the Changshu Agroecological Experimental station, Chinese Academy of Sciences.

Table 3 Rice varieties, number, phytolith content, C content of phytoliths, PhytOC of rice plants on a dry weight basis, and estimated PhytOC fluxes per ha in $\mathrm{Mg}$ of $\mathrm{CO}_{2}$ equivalents $\left(\mathrm{Mg}-\mathrm{e}-\mathrm{CO}_{2}\right)$ for rice (according to grain yields of single and double rice crops) ${ }^{a}$

\begin{tabular}{|c|c|c|c|c|c|}
\hline Varieties & $n$ & $\begin{array}{l}\text { Phytolith content } \\
\left(\mathrm{mg} \mathrm{g}^{-1}\right)\end{array}$ & $\begin{array}{l}\text { C content of phytoliths } \\
\left(\mathrm{mg} \mathrm{g}^{-1}\right)\end{array}$ & $\begin{array}{l}\text { PhytOC content in } \\
\text { dry plant weight }\left(\mathrm{mg} \mathrm{g}^{-1}\right)\end{array}$ & $\begin{array}{l}\text { Estimated PhytOC fluxes } \\
\left(\mathrm{Mg}-\mathrm{CO}_{2} \text { per ha per year) }\right.\end{array}$ \\
\hline Indica rice & 3 & $57.87 \pm 3.52 \mathrm{a}$ & $2.90 \pm 1.39 \mathrm{a}$ & $0.21 \pm 0.11 \mathrm{a}$ & $0.010-0.021$ \\
\hline Indica three line hybrid rice & 14 & $67.21 \pm 6.00 \mathrm{a}$ & $2.46 \pm 1.10 \mathrm{a}$ & $0.19 \pm 0.12 \mathrm{a}$ & $0.012-0.024$ \\
\hline Indica glutinous rice & 2 & $62.57 \pm 3.06 \mathrm{a}$ & $2.10 \pm 0.46 \mathrm{a}$ & $0.13 \pm 0.03 a$ & $0.011-0.022$ \\
\hline Japonica rice & 27 & $59.63 \pm 9.35 a$ & $2.54 \pm 0.91 \mathrm{a}$ & $0.15 \pm 0.06 \mathrm{a}$ & $0.009-0.017$ \\
\hline Japonica three line hybrid rice & 2 & $67.52 \pm 5.20 \mathrm{a}$ & $2.32 \pm 0.68 \mathrm{a}$ & $0.15 \pm 0.02 \mathrm{a}$ & $0.010-0.021$ \\
\hline Japonica glutinous rice & 3 & $63.38 \pm 10.44 a$ & $3.09 \pm 1.86 \mathrm{a}$ & $0.21 \pm 0.15 \mathrm{a}$ & $0.009-0.018$ \\
\hline
\end{tabular}

${ }^{a}$ Data obtained from the Changshu Agroecological Experimental Station, Chinese Academy of Sciences.

\subsection{The potential of securely bio-sequestered $\mathrm{C}$ in rice cultivars}

As shown in Table 4 (Panels A and B), the coefficient of the variation in the phytolith and $\mathrm{C}$ contents of phytoliths of plants of indica and japonica rice cultivars was high, illustrating considerable variation among these rice cultivars. Compared with japonica rice cultivars, the coefficient of variation for the phytolith content and $\mathrm{C}$ contents of phytoliths of plants of the indica rice cultivars was higher, indicating that the variation among indica rice cultivars was greater (Table 4$)$. The results demonstrated that there was no relationship $(R=0.170, p>$ 0.05 ) between the $\mathrm{C}$ contents of phytoliths and the phytolith 
Table 4 Performance and variance of rice cultivars, phytolith content, $\mathrm{C}$ content of phytoliths, PhytOC of rice plants on a dry weight basis, and estimated PhytOC fluxes per ha in $\mathrm{Mg}$ of $\mathrm{CO}_{2}$ equivalents for rice

\begin{tabular}{|c|c|c|c|c|}
\hline \multicolumn{5}{|l|}{ Panel A: indica rice cultivars } \\
\hline Maximum value & 77.15 & 7.21 & 0.51 & 0.018 \\
\hline Range & 23.32 & 5.77 & 0.42 & 0.010 \\
\hline Mean & 65.25 & 2.62 & 0.19 & 0.011 \\
\hline \multicolumn{5}{|c|}{ Panel B: japonica rice cultivars } \\
\hline Minimum value & 45.64 & 1.56 & 0.08 & 0.006 \\
\hline Maximum value & 78.89 & 5.24 & 0.38 & 0.018 \\
\hline Range & 33.25 & 3.68 & 0.30 & 0.012 \\
\hline Mean & 60.47 & 2.58 & 0.16 & 0.009 \\
\hline
\end{tabular}

content of these materials (Table 5). It has previously been shown that the $\mathrm{C}$ contents of phytoliths in bamboo, wheat, sugarcane, and millet is not directly correlated with the phytolith content absorbed by the plant..$^{\mathbf{4 2 1 , 2 2 , 4 2}}$ These data indicate that for rice, wheat, bamboo and sugarcane, it is the efficiency by which $\mathrm{C}$ is encapsulated by $\mathrm{Si}$ within the epidermal cell walls (phytoliths), rather than the actual quantity of Si taken up by the plant, that is most important to determining the relative PhytOC yield in plant materials.

In fact, the $\mathrm{C}$ contents of phytoliths primarily depended on the efficiency of the $\mathrm{C}$ occluded within phytoliths during plant growth. Genetic and physiological differences within rice cultivars could also affect the formation and efficiency of the $\mathrm{C}$ occluded within phytoliths. ${ }^{48}$ However, the C contents of phytoliths was significantly correlated with the PhytOC content in dry plant weight in the 51 rice cultivars $(R=0.804, p<0.01)$ (Table 5) and with the PhytOC content in dry plant weight in 6 rice varieties $(R=0.864, p<0.05)$ (Table 6). Similarly Guo et al., Li et al. and Prajapati et al. reported that the PhytOC content in dry plant weight was the significantly correlated with the content of phytoliths and the $\mathrm{C}$ content of phytoliths, implying that the PhytOC content in dry plant weight depends not only on the content of phytolith but also on the C content of phytolith. ${ }^{6,8,14}$ Thus, how to increase phytolith content and the $\mathrm{C}$ content of phytoliths will require further in-depth study.

The global rice-planting area was approximately $1.64 \times 10^{8}$ ha in $2014 .^{14}$ Considering that the largest PhytOC flux of rice plants was $0.035 \mathrm{Mg}$-e- $\mathrm{CO}_{2}$ per ha per year, globally, $5.74 \times 10^{6}$ $\mathrm{Mg}$-e- $\mathrm{CO}_{2}$ would have been occluded within the phytolith of rice plants per year, ${ }^{6}$ although the annual $\mathrm{CO}_{2}$ occlusion within the

Table 5 Correlation coefficients between four variables of the 51 rice cultivars

\begin{tabular}{llll}
\hline Variables & $\begin{array}{l}\text { Phytolith } \\
\text { content }\end{array}$ & $\begin{array}{l}\text { C content of } \\
\text { phytoliths }\end{array}$ & $\begin{array}{l}\text { PhytOC content } \\
\text { in dry plant weight }\end{array}$ \\
\hline Phytolith content & 1 & & $\begin{array}{l}\text { Estimated } \\
\text { PhytOC fluxes }\end{array}$ \\
C content of phytoliths & 0.170 & 1 & 1 \\
PhytOC content in dry plant weight & $0.505^{a}$ & $0.804^{a}$ & $0.727^{a}$
\end{tabular}

${ }^{a}$ Correlation is significant at the 0.01 level (2-tailed).

Table 6 Correlation coefficients between four variables of the 6 rice varieties

\begin{tabular}{llll}
\hline Variables & $\begin{array}{l}\text { Phytolith } \\
\text { content }\end{array}$ & $\begin{array}{l}\text { C content of } \\
\text { phytoliths }\end{array}$ & $\begin{array}{l}\text { PhytOC content } \\
\text { in dry plant weight }\end{array}$ \\
\hline Phytolith content & 1 & & \\
C content of phytoliths & -0.392 & 1 & 1 \\
PhytOC content in dry plant weight & -0.076 & $0.864^{a}$ & -0.670
\end{tabular}

${ }^{a}$ Correlation is significant at the 0.01 level (2-tailed). 
rice phytoliths of the unit area is likely lower than that of other plants, such as bamboo leaf litter $\left(1.56 \times 10^{7}{\mathrm{Mg}-\mathrm{e}-\mathrm{CO}_{2} \text { per }}\right.$ year $)^{30}$ and wetland plants $\left(4.39 \times 10^{7} \mathrm{Mg}\right.$-e- $\mathrm{CO}_{2}$ per year $),{ }^{8}$ and grasslands $\left(4.14 \times 10^{7} \mathrm{Mg}-\mathrm{e}-\mathrm{CO}_{2}\right.$ per year $){ }^{3}$ and higher than millet $\left(2.37 \times 10^{6} \mathrm{Mg} \text {-e- } \mathrm{CO}_{2} \text { per year }\right)^{5}$ and sugarcane leaf $(0.72$ $\times 10^{7} \mathrm{Mg}$-e- $\mathrm{CO}_{2}$ per year). ${ }^{31}$ In this study we had showed that estimated PhytOC fluxes in rice cultivars varied considerably between different rice cultivars. So the selection of high phytOC rice cultivars became one of effective measure to improve securely bio-sequestered $\mathrm{C}$ in rice crops.

\section{Conclusion}

The C contents of phytoliths was significantly different among the 51 rice cultivars. The $\mathrm{C}$ contents of phytoliths ranged from 1.21 to $7.21 \mathrm{mg} \mathrm{g}^{-1}$, showing high coefficient of variation among rice cultivars. In addition, high variation coefficients of phytolith and contents of phytoliths of plant in indica and japonica rice cultivars implied considerable variation among these rice cultivars. This provides us a feasible way to select rice varieties with high PhytOC content. In this study, we estimated that the PhytOC flux of rice cultivars ranges from 0.006 to 0.035 $\mathrm{Mg}$-e- $\mathrm{CO}_{2}$ per ha per year. Totally, rice plants might sequester $0.18 \times 10^{6}$ to $1.06 \times 10^{6} \mathrm{t} \mathrm{CO}_{2}$ equivalents per year in China. Given the global rice area of $1.64 \times 10^{8}$ ha and the largest flux (0.035 Mg-e- $\mathrm{CO}_{2}$ per ha per year) of the estimated PhytOC flux of rice plants, that approximately $5.43 \times 10^{6} \mathrm{t} \mathrm{CO}_{2}$ equivalents per year would have been sequestrated in the phytoliths of rice plants all over the world. Therefore, selection/breeding of rice cultivars with high PhytOC contents might provide a new approach for increasing atmospheric $\mathrm{CO}_{2}$ bio-sequestration through phytoliths, offering a potential opportunity.

\section{Conflicts of interest}

There are no conflicts of interest to declare.

\section{Acknowledgements}

This work was partially supported through the National Natural Science Foundation of China (No. 41271208), the National Natural Science Foundation of China (No. 31400464), the National Natural Science Foundation of China (No. 31370422), and Anhui Province University Natural Science Research Foundation (KJ2017A423), and Chuzhou University scientific research Foundation (2016qd11).The authors would like to thank Ms Wen Feng and Ms Yilan Liu for assistance with sampling.

\section{References}

1 C. C. Perry, R. J. P. Williams and S. C. Fry, J. Plant Physiol., 1987, 126, 437-448.

2 S. Rajendiran, M. V. Coumar, S. Kundu, M. L. Dotaniya and A. S. Rao, Curr. Sci., 2012, 103, 911-920.

3 Z. Song, H. Liu, Y. Si and Y. Yin, GCB Bioenergy, 2012, 18, 3647-3653.
4 X. X. Zuo and H. Y. Lü, Chin. Sci. Bull., 2011, 56, 3451-3456.

5 W. Pan, Z. Song, H. Liu, K. Müeller, X. Yang, X. Zhang, Z. Li, X. Liu, S. Qiu and Q. Hao, Geoderma, 2017, 308, 86-92.

6 Z. Li, Z. Song, J. F. Parr and H. Wang, Plant Soil, 2013, 370, 615-623.

7 Z. Li, Z. Song and P. Jiang, Chin. Sci. Bull., 2013, 58, 24802487.

8 F. Guo, Z. Song, L. Sullivan, H. Wang, X. Liu, X. Wang, Z. Li and Y. Zhao, Sci. Bull., 2015, 60, 591-597.

9 Y. J. Wang, J. Oceanogr. Huanghai Bohai Seas, 1998, 16, 33-38. 10 L. H. P. Jones and A. A. Milne, Plant Soil, 1963, 18, 358-371.

11 N. Ru, Z. Song, H. Liu, X. Liu, F. Guo, X. Zhang and X. Wu, Silicon, 2016, 1-10.

12 I. E. Pamirsky, A. G. Klykov, G. A. Murugova and K. S. Golokhvast, IOP Conf. Ser.: Mater. Sci. Eng., 2017, 225, DOI: $10.1088 / 1757-1899 X / 1225 / 1081 / 012238$.

13 T. K. Trinh, T. T. H. Nguyen, N. N. Tu, T. Y. Wu, A. A. Meharg and M. N. Nguyen, Soil Tillage Res., 2017, 171, 19-24.

14 K. Prajapati, S. Rajendiran, M. Vassanda Coumar, M. L. Dotaniya, Ajay, S. Kundu, J. K. Saha and A. K. Patra, Appl. Ecol. Environ. Res., 2016, 14, 265-281.

15 L. Qi, F. Y. Li, Z. Huang, P. Jiang, T. Baoyin and H. Wang, Sci. Total Environ., 2017, 577, 413-417.

16 W. Pan, Z. Song, H. Liu, L. V. Zwieten, Y. Li, X. Yang, Y. Han, X. Liu, X. Zhang and Z. Xu, J. Soils Sediments, 2017, 17, 24202427.

17 Z. Song, K. Mcgrouther and H. Wang, Earth-Sci. Rev., 2017, DOI: 10.1016/j.earscirev.2016.1011.1001.

18 B. Li, Z. Song, H. Wang, Z. Li, P. Jiang and G. Zhou, Sci. Rep., 2014, 4, 52-62.

19 J. F. Parr and L. A. Sullivan, Soil Biol. Biochem., 2005, 37, 117124.

20 Z. Song, H. Wang, P. J. Strong and F. Guo, Eur. J. Agron., 2014b, 53, 10-15.

21 J. F. Parr, L. Sullivan, B. Chen, Y. E. Gongfu and W. Zheng, GCB Bioenergy, 2010, 16, 2661-2667.

22 J. Parr, L. Sullivan and R. Quirk, Sugar Tech, 2009, 11, 17-21.

23 Z. Song, H. Liu, S. Cae, X. Yang and X. Zhang, Sci. Total Environ., 2017, 603-604, 502-509.

24 Z. Song, K. Mcgrouther and H. Wang, Earth-Sci. Rev., 2016, 158, 19-30.

25 Z. Ji, X. Yang, Z. Song, H. Liu, X. Liu, S. Qiu, J. Li, F. Guo, Y. Wu and X. Zhang, Grass Forage Sci., 2017, DOI: 10.1111/ gfs.12316.

26 L. H. P. Jones, K. A. Handreck and A. G. Norman, Adv. Agron., 1967, 19, 107-149.

27 L. P. Wilding, R. E. Brown and N. Holowaychuk, Soil Sci., 1967, 103, 56-61.

28 L. P. Wilding, Clay Clay Miner., 1974, 22, 295-306.

29 D. M. Hart and G. S. Humphreys, Quaternary Australia, 1997, 15, 17-25.

30 J. F. Parr, Geoarchaeology, 2006, 21, 171-185.

31 W. L. Lindsay, Clay Clay Miner., 1979, 28, 319.

32 C. A. E. Strömberg, Palaeogeogr., Palaeoclimatol., Palaeoecol., 2004, 207, 239-275.

33 V. Prasad, C. A. Strömberg, H. Alimohammadian and A. Sahni, Science, 2005, 310, 1177-1180. 
34 R. M. Gifford, Aust. J. Plant Physiol., 1994, 21, 1-15.

35 P. Falkowski, R. J. Scholes, E. Boyle, J. Canadell, D. Canfield, J. Elser, N. Gruber, K. Hibbard, P. Högberg and S. Linder, Science, 2000, 290, 291-296.

36 S. Kosten, F. Roland, D. M. L. D. M. Marques, E. H. V. Nes, N. Mazzeo, L. D. S. L. Sternberg, M. Scheffer and J. J. Cole, Global Biogeochem. Cycles, 2010, 24, 1063.

37 S. Piao, J. Fang, P. Ciais, P. Peylin, Y. Huang, S. Sitch and T. Wang, Nature, 2009, 458, 1009-1013.

38 D. F. Zhu, Y. P. Zhang, H. Z. Chen, J. Xiang and Y. K. Zhang, Sci. Agric. Sin., 2015, 48, 3404-3414.

39 Z. Song, K. Müller and H. Wang, Earth-Sci. Rev., 2014a, 139, 268-278.

40 X. Sun, Q. Liu, J. Gu, X. Chen and K. Zhu, Front. Earth Sci., 2016, 10, 683-690.
41 J. F. Parr and L. A. Sullivan, Plant Soil, 2014, 374, 45-53.

42 J. F. Parr and L. A. Sullivan, Plant Soil, 2011, 342, 165-171.

43 Y. Zhao, Z. Song, X. Xu, H. Liu, X. Wu, Z. Li, F. Guo and W. Pan, Ecol. Res., 2016, 31, 117-123.

44 S. W. Blecker, R. L. Mcculley, O. A. Chadwick and E. F. Kelly, Global Biogeochem. Cycles, 2006, 20, 4253-4274.

45 S. Wang, C. Zhang, F. Hu, K. Zeng, W. Zhang and W. Wang, Chinese Agr. Sci. Bull., 2008, 24, 201-205, (in Chinese).

46 J. Alvarez and L. E. Datnoff, Crop Prot., 2001, 20, 43-48.

47 Y. Liang, H. Hua, Y. G. Zhu, J. Zhang, C. Cheng and V. Römheld, New Phytol., 2006, 172, 63-72.

48 J. Mecfel, S. Hinke, W. A. Goedel, G. Marx, R. Fehlhaber, E. Bäucker and O. Wienhaus, J. Plant Nutr. Soil Sci., 2010, 170, 769-772. 